\title{
Circulating tumor DNA and plasma microsatellite instability during PD-1 blockade
}

\author{
Pashtoon M. Kasi \\ College of Medicine and Oncology, University of Iowa, Iowa City, IA 52242, USA \\ Correspondence to: Pashtoon M. Kasi. College of Medicine and Oncology, University of Iowa, Iowa City, IA, USA. Email: pashtoon-kasi@uiowa.edu. \\ Provenance and Peer Review: This article was a free submission to the journal. The article was not sent for external peer review.
}

Submitted Jun 02, 2020. Accepted for publication Jul 31, 2020.

doi: $10.21037 /$ jgo-20-228

View this article at: http://dx.doi.org/10.21037/jgo-20-228

Pembrolizumab was the first tumor-agnostic drug approved by the Food and Drug Administration for treatment of microsatellite instability (MSI)-high tumors (1). These tumors respond to immunotherapy secondary to their hypermutated nature leading to more neoantigens (2). MSI is determined by various tumor tissue assays. However, plasma-based commercially available assays ("liquid biopsies") can be used to assess not only the circulating tumor DNA (ctDNA) but also MSI (3). Furthermore, serial changes in the ctDNA and/or presence or absence of MSI in plasma can quickly capture responders to immune checkpoint blockade. Intriguingly, this can be noted within weeks of administration. Here we show cases where serial assessment was available and predicted response $6-10$ weeks prior to standard imaging (Figure 1).

Not surprisingly, the loss of ctDNA clones coincides with the loss of MSI in plasma. Previously, this was not known how early one can detect changes and response to immunotherapy. Some groups have shown the decrease in the amount of ctDNA predicts responders to immunotherapy or targeted therapies $(4,5)$. However, the fact you can non-invasively test for MSI alongside ctDNA, both can be used early on in the course of one's treatment to separate out responders from non-responders. This is particularly of value in the treatment of MSI-high tumors since now we have single agents as well as combination immunotherapies approved. It is not clear if the combination is superior over single agent for this indication. Utilizing the serial assessment of ctDNA paired with MSI could serve as an early predictive biomarker of response.

Our observations are more than hypothesis generating. Systematically designing studies incorporating serial assessment of ctDNA and MSI status in real-time are very feasible given the rapid turnaround (7-10 days) and non-invasive nature of liquid biopsies. This is timely and important given the increasing number of indications for which immunotherapy is being used. Also, given now the ASCO Plenary KEYNOTE-177 study (NCT02563002) with single agent immunotherapy with pembrolizumab for MSI-High colorectal cancers (CRCs), this would be of value since a third of these patients do not respond to immunotherapy (6). When to switch strategies to chemotherapy and/or combination immunotherapy, assessment of ctDNA and plasma-MSI can serve as integral dynamic biomarkers of predicting early response or lack thereof. 


\begin{tabular}{|c|c|c|c|c|c|c|c|c|c|c|}
\hline & & Baseline & Week 2 & Week 3 & Week 4 & Week 6 & Week 8 & Week 10 & Week 12 & Imaging \\
\hline \multirow[t]{2}{*}{ Patient 1-MSI-high pancreas } & ctDNA highest VAF & $0.7 \%$ & & & ND & & ND & & ND & \multirow{2}{*}{ Response } \\
\hline & MSI-high plasma & + & & & $\mathrm{x}$ & & $\mathrm{x}$ & & $\mathrm{x}$ & \\
\hline \multirow[t]{2}{*}{ Patient 2-MSI-high CRC } & ctDNA highest VAF & $0.4 \%$ & & & & ND & & & & \multirow{2}{*}{ Response } \\
\hline & MSI-high plasma & + & & & & $\mathrm{x}$ & & & & \\
\hline \multirow[t]{2}{*}{ Patient 3-MSI-high CRC } & ctDNA highest VAF & $0.7 \%$ & & & & & ND & & & \multirow{2}{*}{ Response } \\
\hline & MSI-high plasma & + & & & & & $x$ & & & \\
\hline \multirow[t]{2}{*}{ Patient 4-MSI-high gastric } & CtDNA highest VAF & $16.4 \%$ & & & $0.3 \%$ & & & ND & ND & \multirow{2}{*}{ Response } \\
\hline & MSI-high plasma & + & & & + & & & $\mathrm{x}$ & $x$ & \\
\hline \multirow[t]{2}{*}{ Patient 5-MSI-high CRC } & ctDNA highest VAF & $42.2 \%$ & & $0.6 \%$ & & & & $0.9 \%$ & & \multirow{2}{*}{ Response } \\
\hline & MSI-high plasma & + & & + & & & & $x$ & & \\
\hline \multirow[t]{2}{*}{ Patient 6-MSI-high esophageal } & ctDNA highest VAF & ND & & & & & & & ND & \multirow{2}{*}{ Response } \\
\hline & MSI-high plasma & + & & & & & & & $x$ & \\
\hline \multirow[t]{2}{*}{ Patient 7-MSI-high CRC } & ctDNA highest VAF & $31.2 \%$ & & $4.4 \%$ & & & & $0.3 \%$ & & \multirow{2}{*}{ Response } \\
\hline & MSI-high plasma & + & & + & & & & + & & \\
\hline \multirow[t]{2}{*}{ Patient 8-MSI-high CRC } & ctDNA highest VAF & $11.7 \%$ & & $20.9 \%$ & & $18.1 \%$ & & & & \multirow{2}{*}{ Progression } \\
\hline & MSI-high plasma & + & & + & & + & & & & \\
\hline \multirow[t]{2}{*}{ Patient 9-MSI-high CRC } & ctDNA highest VAF & $0.2 \%$ & & & & & & & $0.8 \%$ & \multirow{2}{*}{ Progression } \\
\hline & MSI-high plasma & + & & & & & & & + & \\
\hline \multirow[t]{2}{*}{ Patient 10-MSI-high CRC } & ctDNA highest VAF & $4.4 \%$ & $2 \%$ & & & & & $10.5 \%$ & & \multirow{2}{*}{ Progression } \\
\hline & MSI-high plasma & + & + & & & & & + & & \\
\hline \multirow[t]{2}{*}{ Patient 11-MSI-high CRC } & ctDNA highest VAF & $0.2 \%$ & & ND & & $0.3 \%$ & & & $0.6 \%$ & \multirow{2}{*}{ Progression } \\
\hline & MSI-high plasma & + & & + & & + & & & + & \\
\hline \multirow[t]{2}{*}{ Patient 12-MSI-high CRC } & ctDNA highest VAF & $2.4 \%$ & & $2.7 \%$ & & $1.7 \%$ & & & & \multirow{2}{*}{ Progression } \\
\hline & MSI-high plasma & + & & + & & + & & & & \\
\hline
\end{tabular}

Figure 1 Serial changes in amount of ctDNA (expressed as highest VAF\%) fraction alongside presence (+) or absence (X) of MSI-high detected in plasma. As noted, the loss of detectable ctDNA clones (ND) coincides with the loss of MSI in the plasma. This happened within weeks in all the non-responders and was absent in non-responders. ctDNA, circulating tumor DNA; VAF, variant allele fraction; MSI, microsatellite instability; CRC, colorectal cancer; ND, not detected.

\section{Acknowledgments}

Funding: None.

\section{Footnote}

Conflicts of Interest: The author has completed the ICMJE uniform disclosure form (available at http://dx.doi. org/10.21037/jgo-20-228). Dr. PMK reports personal fees from Natera, personal fees from Foundation Medicine, outside the submitted work.
Ethical Statement: The author is accountable for all aspects of the work in ensuring that questions related to the accuracy or integrity of any part of the work are appropriately investigated and resolved.

Open Access Statement: This is an Open Access article distributed in accordance with the Creative Commons Attribution-NonCommercial-NoDerivs 4.0 International License (CC BY-NC-ND 4.0), which permits the noncommercial replication and distribution of the article with 
the strict proviso that no changes or edits are made and the original work is properly cited (including links to both the formal publication through the relevant DOI and the license). See: https://creativecommons.org/licenses/by-nc-nd/4.0/.

\section{References}

1. Le DT, Durham JN, Smith KN, et al. Mismatch repair deficiency predicts response of solid tumors to PD-1 blockade. Science 2017;357:409-13.

2. Le DT, Uram JN, Wang H, et al. PD-1 blockade in tumors with mismatch-repair deficiency. N Engl J Med 2015;372:2509-20.

3. Kasi PM. Mutational burden on circulating cell-free tumor-
DNA testing as a surrogate marker of mismatch repair deficiency or microsatellite instability in patients with colorectal cancers. J Gastrointest Oncol 2017;8:747-8.

4. Anagnostou V, Forde PM, White JR, et al. Dynamics of tumor and immune responses during immune checkpoint blockade in non-small cell lung cancer. Cancer Res 2019;79:1214-25.

5. Phallen J, Leal A, Woodward BD, et al. Early noninvasive detection of response to targeted therapy in non-small cell lung cancer. Cancer Res 2019;79:1204-13.

6. Andre T, Shiu KK, Kim TW, et al. Pembrolizumab versus chemotherapy for microsatellite instability-high/mismatch repair deficient metastatic colorectal cancer: the phase 3 KEYNOTE-177 study. J Clin Oncol 2020;38:LBA4.
Cite this article as: Kasi PM. Circulating tumor DNA and plasma microsatellite instability during PD-1 blockade. J Gastrointest Oncol 2020;11(4):826-828. doi: 10.21037/jgo-20-228 